\title{
Antibacterial Effect of Irradiated Sugar Solution
}

\author{
Effect of Irradiated Glucose, Fructose and Sucrose \\ Solutions on the Growth of E. coli
}

\author{
Mitsuo Namiki, Yoshihisa Watanabe, Joji Okumura and Shunro KaWakishr \\ Department of Food Science and Technology, Faculty of Agriculture, Nagoya University, Nagoya
}

Received July 28,1972

\begin{abstract}
Effects of irradiated sugar solutions on the growth and viability of $E$. coli $\mathrm{B}$ were investigated on glucose, fructose and sucrose. The antibacterial effect was demonstrated to be classified into two types; the bactericidal effect was developed in every sugar solutions irradiated in air, while the bacteriostatic effect was found especially in fructose irradiated in air free. The bactericidal activity was abolished by heating, $\mathrm{pH}$ change to alkali, and addition of catalase or ferrous ions, suggesting its entity is a peroxide products(s). No appreciable activity was observed with the radiation produced hydrogen peroxide and low molecular carbonyl compounds with each alone and even with their combination. Behaviours of the bacteriostatic activity on similar treatments indicate that the entity is unlikely a peroxide compound but a more thermostable and thiol reactive product.
\end{abstract}

It has been known that the sugar solutions or sugar containing media exposed to UV or ionizing radiation inhibit the growth and multiplication of microorganisms, ${ }^{1 \sim 5}$ plant cells, ${ }^{6,7)}$ and mammalian cells, ${ }^{8,9}$ and moreover they provoke chromosomal aberration or mutation in some plant cells, ${ }^{10,11)}$ bacteria, ${ }^{12)}$ insect, ${ }^{13,14}$ and mammalian cells. ${ }^{9)}$ These effects of irradiated sugar solutions have recently received much attention in the investigations on the safty of irradiated foods, ${ }^{7,15,16)}$ and on the indirect mechanism of radiation effect on biological system. ${ }^{17,18)}$

The growth inhibitory effects have previously been ascribed to the formation of a nonvolatile, diffusible, and thermolabile toxic substance(s) in radiolytic products. ${ }^{1)}$ Recent works have indicated a potentiality of some dicarbonyl compounds ${ }^{8,19}$, and their hydroperoxy derivatives as the toxic principle. However, the development of the growth inhibitory effect seems to be greatly influenced by various irradiation conditions, and the toxic principle has not yet been identified.

$\uparrow$ This work was presented at the Annual Meeting of Agricultural Chemical Society of Japan at Fukuoka, April 1, 1970.
To clarify this situation, we have investigated the effects of conditions during and after irradiation on the development of the antibacterial activity as well as the relationships between the activity and chemical structure of the irradiated sugar. The present report deals mainly with the antibacterial effect of irradiated glucose, fructose, and sucrose solutions on the growth and viability of E. coli $\mathrm{B}$.

\section{MATERIALS AND METHODS}

1. Materials, The sugars (D-glucose, D-fructose, and sucrose) and other reagents used were Guaranteed Grade reagent. The sugar solutions to be irradiated were prepared with triply-distilled water or $0.067 \mathrm{M}$ phosphate buffer, and except otherwise noted they were made up to 1.0 per cent.

2. Irradiation. Irradiations were carried out at $20^{\circ} \mathrm{C}$ with ${ }^{60} \mathrm{Co} \gamma$-rays at dose rate ranging from 1 to $10 \times 10^{4} \mathrm{rads} / \mathrm{h}$. The sugar solutions were irradiated with aeration (in air) or after the removal of air by bubbling with purified nitrogen gas prior to irradiation (in $\mathrm{N}_{2}$ ).

3. Microorganism and media. Escherichia coli B was used as a test microorganism in this experiment. The cells preincubated for about $20 \mathrm{hr}$ in the following medium with shaking were harvested at the end of 
log phase and washed by centrifugation. The cell suspensions of $10^{6}$ to $10^{7} \mathrm{cells} / \mathrm{ml}$ were prepared with $0.067 \mathrm{M}$ phosphate buffer.

Medium for shaking culture: To minimize the modification of the antibacterial effect by nutrient components, the following synthetic medium was used: $\mathrm{KH}_{2} \mathrm{PO}_{4}, 13.6 \mathrm{~g} ; \mathrm{NaCl}, 0.5 \mathrm{~g} ; \mathrm{MgSO}_{4} \cdot 7 \mathrm{H}_{2} \mathrm{O}, 0.2 \mathrm{~g}$; $\left(\mathrm{NH}_{4}\right)_{2} \mathrm{SO}_{4}, 2.0 \mathrm{~g} ; \mathrm{FeSO}_{4} \cdot 7 \mathrm{H}_{2} \mathrm{O}, 0.0005 \mathrm{~g}$; sugar, $4.0 \mathrm{~g}$ in 1 liter distilled water. The $\mathrm{pH}$ was adjusted to 7.0.

Medium for colony count: Meat extract, $10 \mathrm{~g}$; peptone, $10 \mathrm{~g} ; \mathrm{NaNO}_{3}, 5.0 \mathrm{~g} ; \mathrm{NaCl}, 5.0 \mathrm{~g}$; agar, $12 \mathrm{~g}$ in 1 liter distilled water.

4. Test of the growth inhibitory activity. The following method was employed in general to determine the growth inhibitory activity. To the sugar solution $(1 \%)$ with or without irradiation, the sugar free culture medium of 2.5 -fold in the mineral concentration and the cell suspension were added, the ratio of the volume being $2: 2: 1$, respectively. The above mentioned shaking culture medium was finally made up with the inoculum size of about $1 \times 10^{6} \mathrm{cells} / \mathrm{ml}$. Incubation was carried out with shaking at $30^{\circ} \mathrm{C}$ in test tubes and the growth curves were made by counting viable cells using the capillary tube method ${ }^{201}$ or by turbidimetry using a Fuji photoelectrometer. The growth inhibitory activity was determined by comparing the incubation time required to give a given turbidity, corresponding to about $1 \times 10^{8} \mathrm{cells} / \mathrm{ml}$, with that of the unirradiated control.

5. Test of the bactericidal activity. Each of the irradiated sugar solutions was mixed with the cell suspension in phosphate buffer to make finally 0.4 per cent of sugar and about $1 \times 10^{6}$ cells $/ \mathrm{ml}$. The mixtures were allowed to stand at room temperature or $4^{\circ} \mathrm{C}$ for 10,20 , or $40 \mathrm{~min}$, and after appropriate decimal dilutions using phosphate buffer the viable cells were determined by colony counting. The controls were treated in the same way except for the irradiation, and the difference in the viable counts between the control and the irradiated was taken as the bactericidal activity induced by the irradiation.

\section{RESULTS}

1. Effect of irradiated sugar solutions on the growth of E. coli $B$

Chainges in the viable counts of $E$. coli $\mathbf{B}$ during incubation with irradiated glucose and fructose solutions are shown in Figures 1, 2 and 3. The glucose solution (Fig. 1) was found to give a marked inhibitory effect only when it was irradiated in the presence of air.

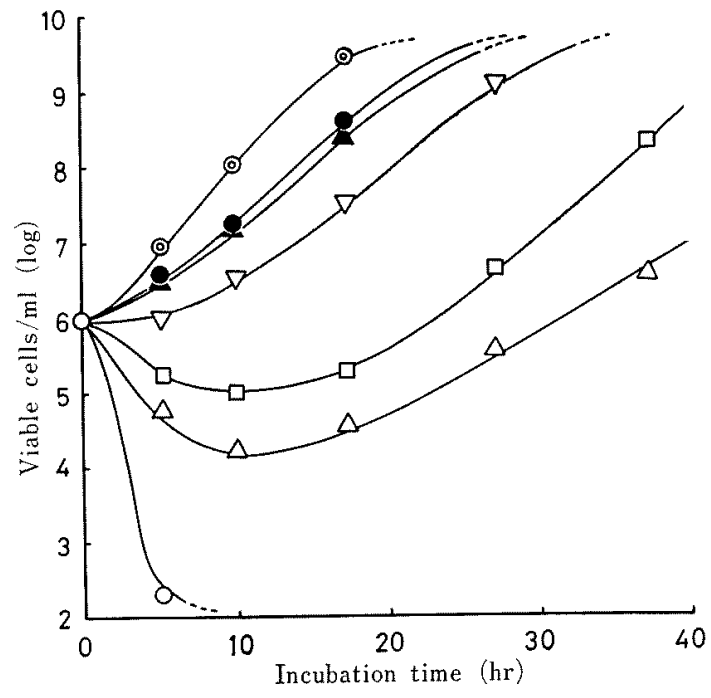

FIG. I. Effect of Irradiated Glucose Solution on the Growth of $E$. coli $\mathrm{B}$.

(2)-(), unirradiated control. -- $-1 \mathrm{Mrad}$ in $\mathrm{N}_{2} . \Delta-\Delta, 2 \mathrm{Mrad}$ in $\mathrm{N}_{2} . \quad \nabla-\nabla, 0.1 \mathrm{Mrad}$ in air. $\square-\square, 0.25 \mathrm{Mrad}$ in air. $\Delta-\Delta, 0.5 \mathrm{Mrad}$ in air. $\bigcirc, 0,1.0 \mathrm{Mrad}$ in air.

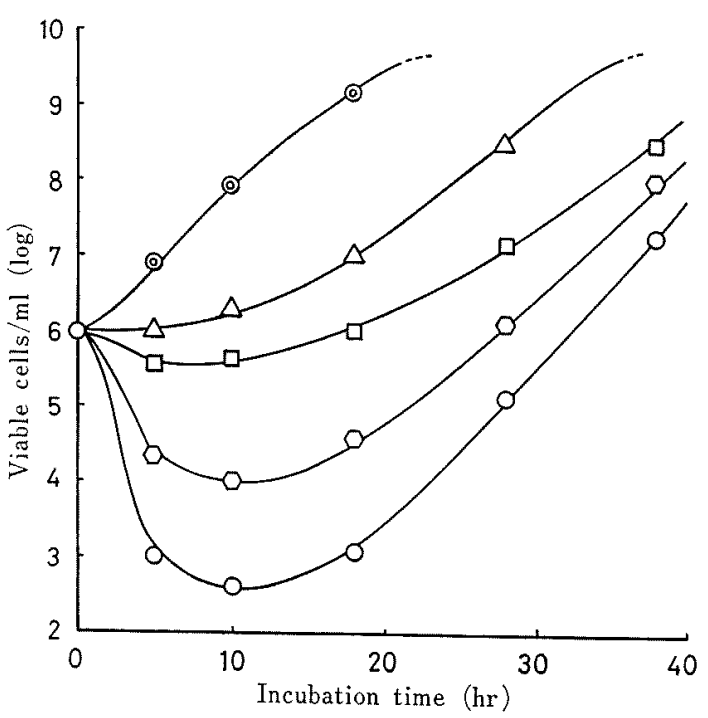

Fio. 2. Effect of Irradiated Fructose Solution on the Growth of E. coli B. (Irradiated in Air).

(๖-९, unirradiated control. $\triangle-\triangle, 0.1$ Mrad. $\square-\square$, $0.25 \mathrm{Mrad} . \quad \bigcirc-0,0.5 \mathrm{Mrad} . \quad \bigcirc-0,1.0 \mathrm{Mrad}$.

There was a significant delay in growth even with a dose of $0.1 \mathrm{Mrad}$ and a strong growth inhibition accompanied by a marked decrease in the viable cells with higher irradiation doses. 


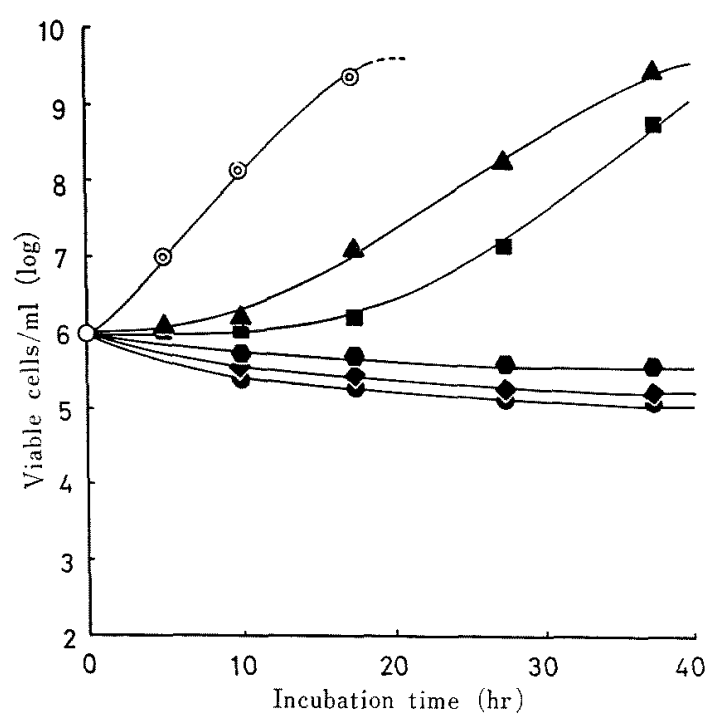

FIG. 3. Effect of Irradiated Fructose Solution on the Growth of $E$. coli $\mathrm{B}$ (Irradiated in $\mathrm{N}_{2}$ ).

(-), unirradiated control. $\Delta-\Delta, 0.1 \mathrm{Mrad}$.

-—, $0.2 \mathrm{Mrad}$. - $\bullet, 0.3 \mathrm{Mrad}$ - $\downarrow, 0.5 \mathrm{Mrad}$.

-, $1.0 \mathrm{Mrad}$.

Interestingly, no appreciable inhibitory effect was observed with the glucose solutions irradiated in the absence of air, except for a slight delay in growth with doses as high as $1.0 \mathrm{Mrad}$ or more.

The fructose solution irradiated in the presence of air (Fig. 2) gave also a strong inhibitory effect and resulted in growth curves similar to those obtained with the glucose solutions irradiated in air. Figure 3 shows the results of the fructose solutions irradiated in air free, where in contrast to glucose, an apparent growth inhibition was observed even with a dose of $1.0 \mathrm{Mrad}$. The incubated media remained clear for over $40 \mathrm{hr}$ during the shaking culture with the solutions irradiated with $0.3 \mathrm{Mrad}$ or more, but there was no appreciable decrease in the viable counts during the incubation.

2. Effect of irradiated sugar solutions on the viability of $E$. coli

In order to make the mode of the antibacterial action of irradiated sugar solutions clear, changes in the viable counts after the treatments with irradiated sugar solutions under different times and temperatures were determined and the results are shown in Table I. A decrease in the viable counts, defined as the bactericidal effect, could be observed only with the sugar solutions irradiated in air and tested at $30^{\circ} \mathrm{C}$ while no effect at $4^{\circ} \mathrm{C}$ on the resting cells in contrast with a striking bactericidal activity of iodineiodide solution.

Table I. Effect of Irradiated Sugar SOLUTIONS ON THE VIABILITY OF E. coli $\mathrm{B}$

Irradiation, 1.0 Mrad in air.

\begin{tabular}{lcc}
\hline $\begin{array}{c}\text { Sugar } \\
\text { irradiated } \\
\text { in air }\end{array}$ & $\begin{array}{c}\text { Incubation } \\
\text { conditions }\end{array}$ & $\begin{array}{c}\text { Viable } \\
\text { cells/ml } \\
(\mathrm{log})\end{array}$ \\
\hline None & $4^{\circ} \mathrm{C}, 40 \mathrm{~min}$ & 6.28 \\
Glucose & $4^{\circ} \mathrm{C}, 40 \mathrm{~min}$ & 6.26 \\
Fluctose & $4^{\circ} \mathrm{C}, 40 \mathrm{~min}$ & 6.26 \\
Sucrose & $4^{\circ} \mathrm{C}, 40 \mathrm{~min}$ & 6.36 \\
Glucose & $30^{\circ} \mathrm{C}, 10 \mathrm{~min}$ & 4.36 \\
Glucose & $30^{\circ} \mathrm{C}, 25 \mathrm{~min}$ & 4.18 \\
Glucose & $30^{\circ} \mathrm{C}, 40 \mathrm{~min}$ & 3.95 \\
Fructose & $30^{\circ} \mathrm{C}, 40 \mathrm{~min}$ & 4.11 \\
I $_{2}$-KI $0.05 \mathrm{mM}$ & $4^{\circ} \mathrm{C}, 40 \mathrm{~min}$ & $<2$ \\
\hline
\end{tabular}

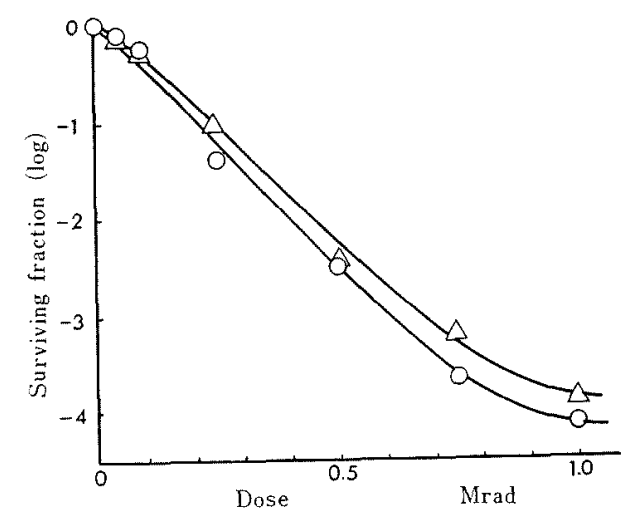

FIG, 4. Relationship between Irradiation Dose and the Bactericidal Activity of Irradiated Sugar Solutions.

0 , glucose. $\Delta$, fructose. Irradiated in air.

Effect of irradiation dose on the development of bactericidal activity is illustrated in Fig. 4. The activity, a decrease in the viable counts, could be detected with a dose as low as $0.1 \mathrm{Mrad}$ and increased almost linearly with 
increasing dose until it saturated at above 1.0 Mrad. As to the dose-activity relationship, glucose and fructose solutions were well coincided with each other.

\section{Effect of $\mathrm{pH}$ change after irradiation on the} antibacterial effects of irradiated sugar solutions.

To see the pH-stability of the antibacterial principles, the irradiated sugar solutions were stored at different $\mathrm{pH}$ values at room temperature before the activity tests. The $\mathrm{pH}$ of the sugar solutions prepared with distilled water dropped to about 3.5 with a dose of 1.0 $\mathrm{Mrad}$, and the $\mathrm{pH}$ adjustment were made by using $1 \mathrm{~N} \mathrm{NaOH}$ and $\mathrm{HCl}$. The activity tests were done after $\mathrm{pH}$ readjustment to 7.0.

The bactericidal activity was tested after standing the treated sugar solutions with the cells at $30^{\circ} \mathrm{C}$ for $40 \mathrm{~min}$. The results shown in Fig. 5 clearly demonstrate that the bactericidal principle(s) of every sugar solutions irradiated in air is stable in acid side but highly labile in alkali as the activity decreased rapidly with increasing $\mathrm{pH}$ above 7.0 until a complete loss at $\mathrm{pH} 10.5$.

The growth inhibitory activity of the sugar solutions after $\mathrm{pH}$ change were given in Fig. 6. The response to the $\mathrm{pH}$ change revealed itself in a similar way though the activity loss in alkali side was not so severe as was in the above case. The inhibitory effect of the fructose solutions irradiated in $\mathrm{N}_{2}$,

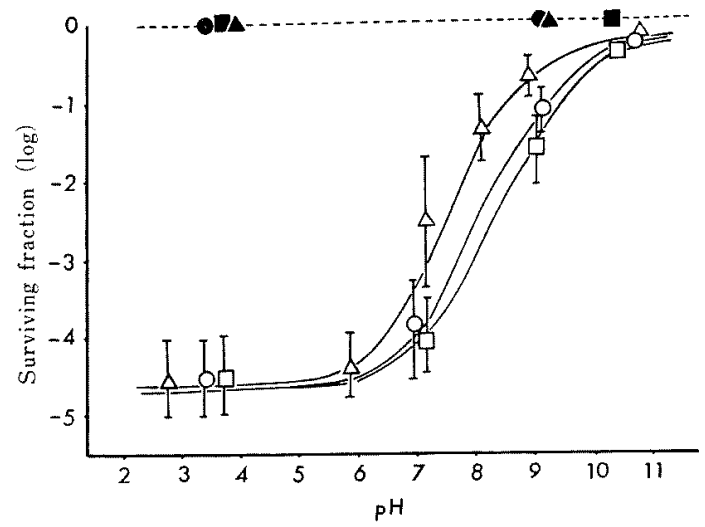

FIG. 5. Effect of pH Change after Irradiation on the Bactericidal Activity of Irradiated Sugar Solutions.

0 , glucose in air. - glucose in $\mathrm{N}_{2} . \Delta$, fructose in air. $\mathbf{A}$, fructose in $\mathrm{N}_{2} . \quad \square$, sucrose in air. $\mathbf{a}$, sucrose in $\mathrm{N}_{2}$. Irradiation $1.0 \mathrm{Mrad}$.

which might be caused by the bactriostatic principle, is found also to be unstable in alkaline medium.

4. Effect of heating after irradiation on the antibacterial effects of irradiated sugar solutions

Understanding the behavior of the antibacterial effects to heating would be of importance in investigating chemical properties of the active principles as well as in understanding the effect of cooking on irradiated foods.

The sugar solutions irradiated with $1.0 \mathrm{Mrad}$ were immediately autoclaved at $120^{\circ} \mathrm{C}$ for 20 ,

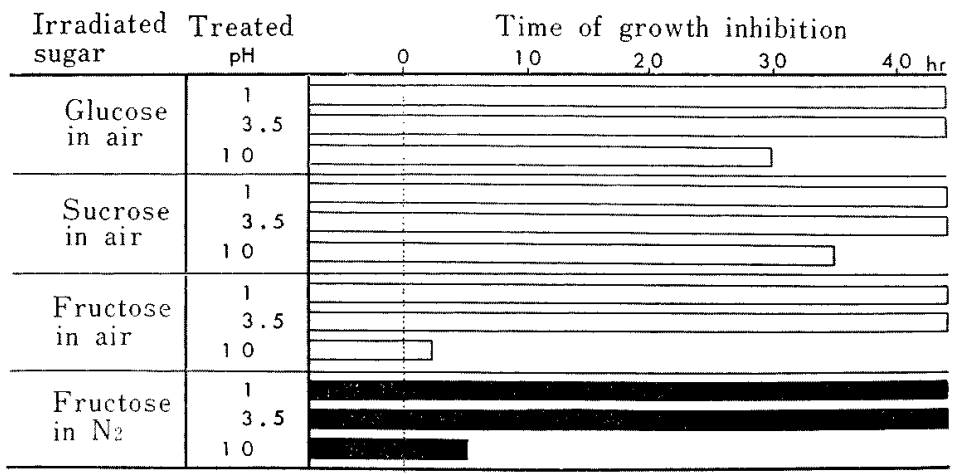

FrG. 6. Effect of pH Change after Irradiation on the Growth Inhibitory Activity of Irradiated Sugar Solutions.

Irradiation, $1.0 \mathrm{Mrad}$. 
40 and $60 \mathrm{~min}$ prior to the activity tests. The preliminary experiments using unirradiated sugar solutions indicated that the heating alone did not induce any bactericidal activity in every sugar solutions, while it did provoke so marked growth inhibition especially in the case of fructose as it was difficult to determine the heating effect on the radiation induced activity.

The results shown in Table II, where the bactericidal activities of the sugar solutions

Table II. Effect of Heating after Irradiation ON THE BACTERICIDAL ACTIVITY OF IRRADIATED SUGAR SOLUtIONS

Irradiation, 1.0 Mrad in air.

\begin{tabular}{cccc}
\hline $\begin{array}{c}\text { Irradiated } \\
\text { sugar }\end{array}$ & Heating & \multicolumn{2}{c}{$\begin{array}{c}\text { Viable cells/ml } \\
(\mathrm{log})\end{array}$} \\
\hline Contol & none & 6.54 & 6.65 \\
Glucose & none & 3.54 & $<2$ \\
in air & $120^{\circ} \mathrm{C}, 20 \mathrm{~min}$ & 6.08 & 6.30 \\
Fructose & none & 4.18 & $<2$ \\
in air & $120^{\circ} \mathrm{C}, 20 \mathrm{~min}$ & 5.40 & 6.00 \\
Sucrose & none & 3.65 & $<2$ \\
in air & $120^{\circ} \mathrm{C}, 20 \mathrm{~min}$ & 5.74 & 5.90 \\
Glucose & none & 6.48 & \\
in $\mathrm{N}_{2}$ & $120^{\circ} \mathrm{C}, 20 \mathrm{~min}$ & 5.81 & \\
Fructose & none & & 6.00 \\
in $\mathrm{N}_{2}$ & $120^{\circ} \mathrm{C}, 20 \mathrm{~min}$ & & 6.23 \\
\hline
\end{tabular}

irradiated in air were completely abolished by heating for $20 \mathrm{~min}$, indicated that the bactericidal principle was a product of highly thermo- labile nature.

On the other hand, as illustrated in Fig. 7, the heating provided rather complicated effects on the inhibitory activity. The activities of glucose and sucrose solutions irradiated in air were tend to decrease with increasing heating time, though there remained the activity to a considerable extent even with heating for $40 \mathrm{~min}$. In the cases of these sugar solutions irradiated in the absence of air, the activities were very weak with the irradiation alone but increased apparently with an increase in the heating time, despite of no such enhancement in their unirradiated controls.

\section{Effect of thiol compound on the antibacterial} effect of irradiated sugar solutions

To investigate whether the antibacterial principles have a specific reactivity to $\mathrm{SH}$ group, $\beta$-mercaptoethanol was added to the irradiated sugar solutions prior to the microbial tests. Figure 8 shows the influence of mercaptoethanol on the growth inhibitory effect of the sugar solutions irradiated with $0.5 \mathrm{Mrad}$. The presence of $0.1 \mathrm{~mm}$ of mercaptoethanol in the testing medium was known to be ineffective on the growth of bacteria. The growth inhibitory activities of the sugar solutions irradiated in air were reduced significantly but not completely lost by the presence of the thiol compound. On the other hand, noticeable effect was observed in the case of sugars

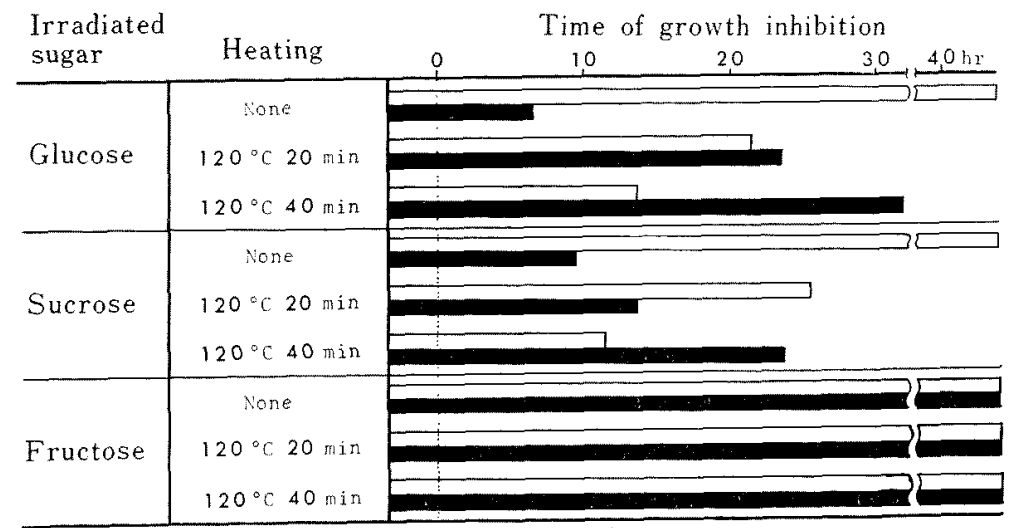

FIG. 7. Effect of Heating after Irradiation on the Growth Inhibitory Activity of Irradiated Sugar Solutions. 


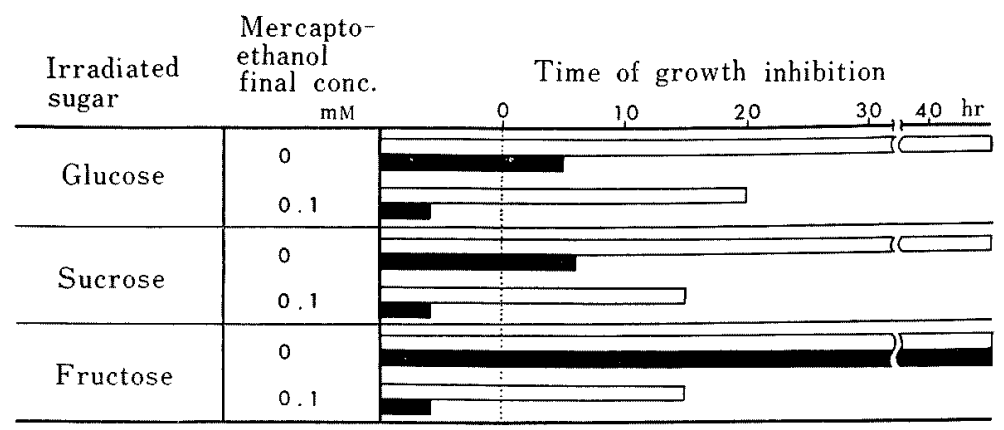

Fig. 8. Effect of Mercaptoethanol on the Growth Inhibitory Effect of Irradiated Sugar Solutions.

—, $0.5 \mathrm{Mrad}$ in air. $0.5 \mathrm{Mrad}$ in $\mathrm{N}_{2}$.

irradiated in the absence of air, where the thiol addition provoked not only a complete loss of the activity but also an apparent acceleration of the growth.

6. Effect of catalase on the antibacterial effects of irradiated sugar solutions

A catalase solution prepared by using a purified beef lever catalase (Sigma, 2400 sigma units per $\mathrm{mg}$ ) with phosphate buffer $\mathrm{pH} 6.0$ was added to the irradiated sugar solutions and after standing for $30 \mathrm{~min}$ at $30^{\circ} \mathrm{C}$ the bactericidal and the growth inhibitory activities were examined.

The results presented in Table III and Fig. 9 indicate that the bactericidal activities of the sugar solutions irradiated in air were abolished almost completely by the addition of 12 units of catalase, while the growth inhibitory effect was found to be fairly resistant to catalase action.
Table III. Effect of Catalase on the Bactericidal ACtivity of IrRadiated Sugar Solutions

Irradiation, 1.0 Mrad in air.

\begin{tabular}{ccc}
\hline $\begin{array}{c}\text { Irradiated } \\
\text { sugar }\end{array}$ & $\begin{array}{c}\text { Catalase } \\
\text { units }\end{array}$ & $\begin{array}{c}\text { Viable cells/ml } \\
(\log )\end{array}$ \\
\hline Control & & 6.65 \\
Glucose & 0 & $<2$ \\
in air & 6 & 5.50 \\
& 12 & 6.20 \\
Fructose & 0 & $<2$ \\
in air & 6 & 4.71 \\
& 12 & 5.50 \\
Sucrose & 0 & $<2$ \\
in air & 6 & 4.50 \\
& 12 & 5.55 \\
\hline
\end{tabular}

7. Effect of metal ions on the bactericidal effect of irradiated sugar solutions

In connection with a high reactivity of some heavy metal ions to a peroxide compound,

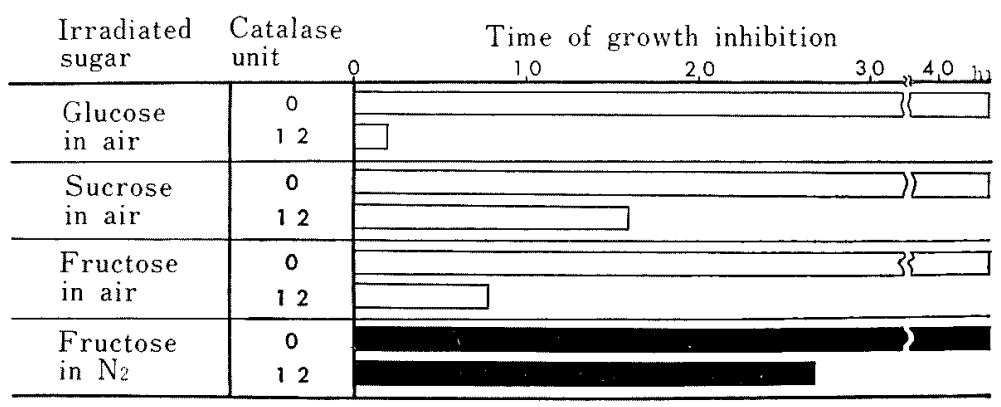

Fug. 9. Effect of Catalase on the Growth Inhibitory Activity of Irradiated Sugar Solutions. Irradiation, $0.5 \mathrm{Mrad}$ in air. 
effects of ferrous, ferric and cobaltic ions on the bactericidal activity of the sugars irradiated in air were examined. To the sugar solutions irradiated with $1.0 \mathrm{Mrad}$ were added the testing metal sulfate or chloride solution and subsequently the cell suspension in phosphate buffer $\mathrm{pH} 7.0$, and the mixtures were then allowed to stand for $40 \mathrm{~min}$ at room temperature prior to the viable counting.

The results given in Table IV indicate that

\section{Table IV. Effect of Metal Ions on the BACTERICIDAL ACtrVITY OF IRRADIATED Sugar Solutions}

Irradiation, 1.0 Mrad in air.

\begin{tabular}{ccc}
\hline Sugar & $\begin{array}{c}\text { Added } \\
\text { metal ion }\end{array}$ & $\begin{array}{c}\text { Viable cells/ml } \\
(\mathrm{log})\end{array}$ \\
\hline Control & None & 6.75 \\
& none & $<2$ \\
Glucose & $\mathrm{Fe}^{2+} 0.1 \mathrm{~mm}$ & 5.30 \\
& $\mathrm{Fe}^{3+} 0.1 \mathrm{~mm}$ & 3.95 \\
& $\mathrm{Co}^{2+} 0.1 \mathrm{mM}$ & $<2$ \\
Sucrose & none & $<2$ \\
& $\mathrm{Fe}^{2+} 0.1 \mathrm{~mm}$ & 5.20 \\
& $\mathrm{Fe}^{3+} 0.1 \mathrm{mM}$ & $<2$ \\
Fructose & none & $<2$ \\
& $\mathrm{Fe}^{2+} 0.1 \mathrm{~mm}$ & 6.50 \\
& $\mathrm{Fe}^{3+} 0.1 \mathrm{mM}$ & 3.42 \\
\hline
\end{tabular}

the bactericidal effect of every sugar solution was more or less influenced by the presence of these heavy metal ions, especially by ferrous ions, with which the activity was abolished almost completely while ferric ions were not so effective.

8. Antibacterial effects of some radiolytic products of sugar

In order to evaluate the potentiality of various radiolytic products of sugar solutions as the toxic principle(s) of the bactericidal and growth inhibitory effects, several carbonyl compounds noted as the principle and hydrogen proxide were tested with each alone or with their combination under the same experimental conditions as employed hereabove.

As shown in Table V, no bactericidal activity was observed with the carbonyl compounds employed here even with $1.0 \mathrm{~mm}$ and only a slight decrease in the viability was found with hydrogen peroxide of up to $2.0 \mathrm{~mm}$ when each of them was used alone. Moreover, there was no appreciable enhancement of the activity in the combined use of the carbonyls with hydrogen peroxide except for that of $0.1 \mathrm{~mm}$ formaldehyde and $0.2 \mathrm{~mm}$ hydrogen peroxide.

The growth inhibitory activity of the radiolytic products are illustrated in Fig. 10. Here, hydrogen peroxide was found to act very effectively even with $0.1 \mathrm{~mm}$, and only formal-

\begin{tabular}{l|c|c}
\multicolumn{1}{c}{ Compound } & Final conc. & Time of growth inhibition \\
& 0.02 \\
& 0.05 \\
$\mathrm{H}_{2} \mathrm{O}_{2}$ & 0.10 \\
& 0.20 \\
& 1.00 \\
\hline $\mathrm{H}_{2} \mathrm{O}_{2}+$ Catalase & 1.0 \\
\hline Formaldehyde & 0.2 \\
\hline Methylglyoxal & 1.0 \\
\hline Acetaldehyde & 0.2 \\
\hline Glycolaldehyde & 1.0 \\
\hline Glyoxal & 1.0 \\
\hline Dihydroxyacetone & 1.0 \\
\hline Glyceraldehyde & 1.0 \\
\hline
\end{tabular}

FIG. 10. The Growth Inhibitory Effect of Hydrogen Peroxide and Carbonyl Compounds on E. coli $\mathbf{B}$. 
Table V Effect of Hydrogen Peroxide and Carbonyl Compounds on the Viability of E. coli B

The cells were incubated with the reagent at $30^{\circ} \mathrm{C}$ for $40 \mathrm{~min}$ in phosphate buffer, $\mathrm{pH} 7.0$, prior to the viable counting. In the cases of combined use of hydrogen peroxide and carbonyl compound, the mixtures were allowed to stand at room temperature for $30 \mathrm{~min}$ prior to the contact with the cells.

\begin{tabular}{|c|c|c|c|c|c|c|}
\hline Compound & $\begin{array}{l}\text { Final } \\
\text { conc. } \\
\text { (mm) }\end{array}$ & \multicolumn{2}{|c|}{$\begin{array}{l}\text { Viable cells } / \mathrm{ml} \\
(\log )\end{array}$} & Compound & $\begin{array}{l}\text { Final } \\
\text { conc. } \\
\text { (mm) }\end{array}$ & $\begin{array}{l}\text { Viable cells } / \mathrm{ml} \\
\text { (log) }\end{array}$ \\
\hline \multirow{6}{*}{$\begin{array}{l}\text { Control } \\
\mathrm{H}_{2} \mathrm{O}_{2}\end{array}$} & none & 5.90 & 6.80 & Control & none & 6.08 \\
\hline & 0.2 & 5.00 & 5.90 & $\mathrm{H}_{2} \mathrm{O}_{2}$ & 1.0 & 5.00 \\
\hline & 0.5 & 4.90 & 5.88 & Glyoxal & 0.2 & 6.04 \\
\hline & 1.0 & 4.64 & & Methylglyoxal & 0.2 & 6.05 \\
\hline & 2.0 & 4.30 & & Formaldehyde & 0.2 & 6.08 \\
\hline & 5.0 & $<2.0$ & & Glycolaldehyde & 0.2 & 6.08 \\
\hline \multirow{3}{*}{$\begin{array}{l}\text { Formaldehyde } \\
\text { Methylglyoxal } \\
\text { Glyoxal }\end{array}$} & 1.0 & 5.66 & 6.30 & Dihydroxyacetone & 0.2 & 6.05 \\
\hline & 1.0 & 5.60 & 6.18 & Glyoxal + & 0.2 & \\
\hline & 1.0 & 5.93 & & $\mathrm{H}_{2} \mathrm{O}_{2}$ & 1.0 & 5.10 \\
\hline \multirow{2}{*}{$\begin{array}{l}\text { Glyceraldehyde } \\
\text { Glycolaldehyde }\end{array}$} & 1.0 & 5.90 & & Methylglyoxal + & 0.2 & 478 \\
\hline & 1.0 & 5.85 & & $\mathrm{H}_{2} \mathrm{O}_{2}$ & 1.0 & \\
\hline Dihydroxyacetone & 4.0 & & 6.07 & $\begin{array}{l}\text { Formaldehyde }+ \\
\mathrm{H}_{2} \mathrm{O}_{2}\end{array}$ & $\begin{array}{l}0.2 \\
1.0\end{array}$ & 4.72 \\
\hline \multirow{2}{*}{$\begin{array}{l}\text { Malondialdehyde } \\
\text { Methylglyoxal + } \\
\mathrm{H}_{2} \mathrm{O}_{2}\end{array}$} & 1.0 & & 6.85 & Glyoxal + & 0.2 & \\
\hline & 1.0 & 4.71 & 5.69 & $\mathrm{H}_{2} \mathrm{O}_{2}$ & 1.0 & 4.80 \\
\hline $\begin{array}{l}\mathrm{H}_{2} \mathrm{O}_{2} \\
\text { Formaldehyde }+ \\
\mathrm{H}_{2} \mathrm{O}_{2}\end{array}$ & $\begin{array}{l}0.2 \\
1.0 \\
0.2\end{array}$ & 3.00 & 3.94 & $\begin{array}{l}\text { Dihydroxyacetone }+ \\
\mathrm{H}_{2} \mathrm{O}_{2}\end{array}$ & $\begin{array}{l}0.2 \\
1.0\end{array}$ & 4.51 \\
\hline $\begin{array}{l}\text { Malondialdehyde }+ \\
\mathrm{H}_{2} \mathrm{O}_{2}\end{array}$ & $\begin{array}{l}1.0 \\
0.2\end{array}$ & & 5.30 & & & \\
\hline $\begin{array}{l}\text { Glyoxal }+ \\
\mathrm{H}_{2} \mathrm{O}_{2}\end{array}$ & $\begin{array}{l}1.0 \\
0.5\end{array}$ & 4.90 & & & & \\
\hline $\mathrm{I}_{2}+\mathrm{KI}$ & 0.005 & $<2.0$ & & & & \\
\hline
\end{tabular}

dehyde and glyoxal were effective when they were presented as high as $1.0 \mathrm{~mm}$.

\section{DISCUSSION}

In spite of various works undertaken on the antibacterial effect of irradiated sugar solutions, little has been known on changes in the viability of bacterial cells during incubation with the irradiated sugar solution, except for the studies by Molin with Pseudomonas ${ }^{2}$ and by Chopra with E. coli, ${ }^{4}$ where they have presented a marked decrease in the viable cells in an early stage of the incubation with the irradiated glucose or glucose containing medium, though they have not noted on the atomosphere during irradiation. The results presented in Figs. 1 to 3 clearly demonstrated that the antibacterial effect of irradiated sugar solutions involved at least two types in the mode of action, the bactericidal and the bacteriostatic, and which type of those effects was greatly dependent upon the presence of air during irradiation as well as on the variety of sugar to be irradiated.

Concerning the bactericidal effect, it was proved that its development required the presence of air during the irradiation of sugar solution and the active product(s) was susceptible to the after irradiation treatments such as heating at $120^{\circ} \mathrm{C}$, storage in alkali, and the addition of catalase or ferrous ions, which resulted in a serious loss of its activity. These facts may support the assumption that, so far as the bactericidal effect is concerned, the antibacterial principle of the irradiated sugar solutions would be a peroxide type product.

In reference to the antibacterial principle of the irradiated sugar solutions, the role of radiation induced peroxide has long been noticed and sometimes assumed as a toxic entity. ${ }^{21,22)}$ On the other hand, in connection with the growth inhibitory and mutagenic 
effects of unsaturated and dicarbonyl compounds on bacteria, ${ }^{23,24)}$ a potentiality as the antibacterial principle of irradiated sugar solutions has been suggested to some carbonyl compounds, such as formaldehyde, ${ }^{24)}$ glyo$\mathrm{xal}^{8,25,26)}$ methylglyoxal, ${ }^{24)}$ and malondialdehyde. ${ }^{27}$ And recently, the secondary products of these carbonyl compounds with hydrogen peroxide, alkyl- and dialkyl-hydroxyperoxides, were proposed as a toxic principle. ${ }^{3,28,293}$

On the radiolytic formation of these compounds from sugar in aqueous system, Phillips et al. have presented ${ }^{30,31}$ G-values for low molecule carbonyls to be $0.3 \sim 0.8$ and for hydrogen peroxide to be 3.0 , the latter being noted as an extraordinarily high value in the case of sugar solutions irradiated in air. According to these data, the actual concentrations of hydrogen peroxide and carbonyl compounds in the testing solutions employed hereabove were estimated to be no more than 1.2 and $0.3 \mathrm{~mm}$ respectively with the irradiation of $1.0 \mathrm{Mrad}$ in air, because the irradiated sugar solutions were diluted 2.5 -hold in the incubation mixtures.

The bactericidal activity test of various radiolytic product involving hydrogen peroxide (Table V) indicated that hydrogen peroxide and the carbonyl compounds so far tested did not exhibit any appreciable activity with each alone even with fairly higher concentrations than those estimated hereabove from their $\mathrm{G}$-values. Moreover, no significant synergistic enhancement in the activity was observed with the combination of hydrogen peroxide and carbonyl compound. On the other hand, as shown in Fig. 1, the bactericidal effect of the irradiated sugar solutions could apparently be observed even with a dose as low as 0.25 Mrad. Thus it seems to be that the bactericidal effect of the irradiated sugar solutions could not be explained well by postulating any of the above mentioned radiolytic products as a toxic principle by itself, though there remained some possibility that an enhanced bactericidal activity resulted from a cumulative effect of various reaction products and/or a presence of some other effective radiolytic product hitherto unidentified.

On the other hand, as to the growth inhibitory effect of the sugar solutions irradiated in the presence of air, it seems reasonable to assume that the effect is mostly resulted from the action of the bactericidal principle. However, the growth inhibitory effect is, as shown in Figs. 6, 7 and 9, not so seriously affected by the after irradiation treatments as was the case of the bactericidal effect, and the activity remained to a certain extent especially in the case of glucose and sucrose. It can therefore be said that the growth inhibition of the sugar solutions irradiated in air is not entirely resulted from the action of the toxic principle identical with that of the bactericidal effect but it would be attributable in part to some other toxic product(s).

The presence of another type of antibacterial effect, the bacteriostatic growth inhibition, is newly demonstrated hereabove with the sugar solutions irradiated in the absence of air, and interestingly it is greatly dependent upon the variety of sugar employed. The results indicate that the inhibitory effect is labile in alkali but not so influenced by catalase addition and heating as in the case of the bactericidal effect of the irradiated sugar solutions, though it was characteristically inactivated by the presence of thiol compound.

These facts imply that the bacteriostatic principle formed in the fructose solution irradiated in air free is unlikely a peroxide type compound but some thermostable radiolytic product highly reactive with thiol compound, and that this feature is presumed to be correlated in some way with the mechanism of the bacteriostatic effect.

The reason why fructose is particularly eminent in the development of bacteriostatic effect is not yet clear; but in our chemical studies on radiolysis of various sugars, we have some evidence that fructose is especially pronounced in the radiolytic formation of a reductone-like substance which can easily react with amino compounds to give a colored product. $^{32)}$ In connection with these results, 
it is to be noted that some kind of reductones has been reported to exhibit a growth inhibitory effect, ${ }^{33}$ ) and moreover the antibacterial effect of some dicarbonyl compounds could effectively be suppressed by the addition of cysteine. ${ }^{24}$

Another interesting fact in the growth inhibitory effect is that the glucose and sucrose solutions irradiated in air free developed the growth inhibitory activity by the heating after irradiation. This after effect suggests that the formation of some radiolytic product of thermolabile nature gives the growth inhibitory substance, likely to the case of unirradiated fructose solution.

From the experimental results throughout this study, there exist considerable differences in the behavior of development of antibacterial effect by irradiation between glucose and fructose, and in this respect, sucrose resembles closely to its one moiety, glucose but not to another, fructose.

In conclusion, here some complicated features of the antibacterial effects of irradiated sugar solutions could be elucidated, but the active principles of either bactericidal or bacteriostatic effects of each sugar solution remain obscure and further chemical and biological investigations are being undertaken.

\section{REFERENCES}

1) I. H. Blank and W. Arnold, J. Bacteriol, 30, 507 (1935).

2) N. Molin and L. Ehrenberg, Int. J. Radiat. Biol., 8, 223 (1964).

3) J. Schubert and F. J. Ratty, ibid., 12, 347 (1967).

4) B. L. Chopra, Mutation Res., 8, 25 (1969).

5) H. E. Frey and E. C. Pollard, Radiat. Res., 36, 59 (1968).

6) P. C. Kesavan and M. S. Swaminathan, Radiat. Botany, 7. 269 (1967).

7) R. D. Holsten, M. Sugii and J. C. Steward, Nature, 208, 850 (1965).
8) R. J. Berry, P. R. Hills and W. Trillwood, Int. J. Radiat. Biol., 9, 559 (1965).

9) M. E. Shar and E. Hayes, Nature, 211, 1254 (1966).

10) M. S. Swaminathan and V. L. Chopra, Radiat. Res., 16, 182 (1962).

11) Te-Hsiu Ma, Radiat. Botany, 8, 307 (1968).

12) V. L. Chopra, A. T. Narajan, and M. S. Swaminathan, Radiat. Botany, 3, 1 (1963).

13) M. S. Swaminathan, A. T. Natarajan and R. P. Sharma, Science, 141, 637 (1963).

14) R. R. Reinhart and F. J. Ratty, Int. J. Radiat. Biol., 12, 347 (1967).

15) S. A. Goldblith, Nature, 210, 433 (1966).

16) M. Moutschen, J. Moutschen and L. Ehrenberg, Int. J. Radiat. Biol, 18, 201 (1970).

17) A. M. Cook and R. J. Bery, Nature, 210, 324 (1966).

18) Y. Makinen, M. D. Upadhya and J. L. Brewbaker, ibid., 214, 413 (1967).

19) R. Jonard, P. Manant and J. Schaeverbek-sacre, Radiat. Botany, 10, 175 (1970).

20) A. Matsuyama, Nippon Nogeikagaku Kaishi, 27, 7 (1953).

21) H. I. Adler and R. I. Clayton, Radiat. Res., 16 746 (1962).

22) H. E. Frey and E. C. Pollard, ibid., 28, 668 (1966).

23) L. G. Együd, Currents in Modern Biol, 1, 14 (1967).

24) L. G. Együd, ibid., 2, 128 (1968).

25) P. R. Hills and R. J. Berry, Nature, 215, 309, (1967).

26) O. L. Klamerth, Biochem. Biophys. Acta, 155, 271 (1968).

27) B. R. Brooks and O. L. Klamerth, European J. Biochim., 5, 178 (1968).

28) J. Schubert and J. A. Watson, Radiat. Res., 37, 531 (1969).

29) J. A. Watson and J. Schubert, ibid., 16, 746 (1962).

30) C. O. Phillips, ibid., 18, 446 (1963).

31) G. O. Phillips, W. Griffith and J. V. Davis, J. Chem.Soc. (B), 1966, 194.

32) S. Kawakishi, J. Okumura and M. Namiki, Nippon Nogeikagaku Kaishi, 46 (9), 459(1972).

33) H. V. Euler and H. Hasselquist, Experimentia, 5, 84 (1949). 